\title{
Economic Aspects of Local Authorities Functioning
}

\author{
Tatyana I. Alyunova ${ }^{1}$, Irina P. Nikolayeva ${ }^{1}$, Liudmila V. Semenova ${ }^{2}$, Sergey V. Kiselev ${ }^{3}$, Guzel F. Yusupova ${ }^{4}$, \\ Albina N. Mayorova ${ }^{5}$, Natalia M. Korsunova ${ }^{6} \&$ Oleg A. Petrov ${ }^{1}$ \\ ${ }^{1}$ Chuvash State Pedagogical University named after I.Y. Yakovlev, Cheboksary, Russia \\ ${ }^{2}$ Immanuel Kant Baltic Federal University, Kaliningrad, Russia \\ ${ }^{3}$ Kazan National Research Technological University, Kazan, Russia \\ ${ }^{4}$ Kazan (Volga region) Federal University, Kazan, Russia \\ ${ }^{5}$ Russian State Social University (Klin branch), Moscow Region, Klin, Russia \\ ${ }^{6}$ Russian Customs Academy, Moscow Region, Lyubertsy, Russia \\ Correspondence: Tatyana I. Alyunova, Chuvash State Pedagogical University named after I.Y. Yakovlev, 428032, \\ Cheboksary, K. Marksa Street, 38, Russia. E-mail: tanjana1@yandex.ru
}

Received: June 13, 2015 Accepted: June 21, 2015 Online Published: June 29, 2015

doi:10.5539/jsd.v8n6p90 URL: http://dx.doi.org/10.5539/jsd.v8n6p90

\begin{abstract}
The relevance of the study on economic aspects of local authorities' functioning is due to their dual nature in the complex system of market relations. In this regard, this article is aimed at economic aspects' revealing of local authorities' functioning, as well as the disclosure of various interest levels' interaction in the system of municipal management. A leading approach in the study of this problem is the method of the effectiveness assessing of local authorities' functioning. The article presents the analysis of domestic researchers' different points of view in relation to the substantial characteristics of municipal economy, reveals the nature of the interaction of various interest levels in the system of municipal relations, discloses the duality of local authorities' position in the municipal system of economic relations, proposes a classification of business entities under the municipal economy, proves the specificity of the economic and moral relations in the system of local authorities. The article is valuable for researchers, teachers and students studying the problems of formation and development of the national municipal economy, research methods within the discipline "Economics of public (government) services", "Municipal economy", as well as specialists of local authorities who are concerned with the improvement and development of municipal economy.
\end{abstract}

Keywords: local authorities, economic basics, levels of interests, dualism, municipal enterprises, municipal property, municipal management

\section{Introduction}

\subsection{The Relevance of the Problem}

The relevance of economic aspects' study of the local authorities' functioning is due to a set of problems and contradictions that are substantially different from traditional economic activities. According to experts' data, $80 \%$ of all free social benefits, guaranteed by the Russian Federation's Constitution, and more than $90 \%$ of the paid services almost every citizen of Russia receives only at the place of his or her permanent residence (Leksin \& Shvetsov, 2001). Therefore the most important task of local authorities is to ensure the most important vital interests and needs of living population on the territory of the municipality, including the provision of them by gas, electricity, sanitation, a number of housing services, services for removal and recycling, services of urban and suburban passenger transport, catering, health services, education, culture and sports and much more. On the other hand, the administration of the municipality has the task of forming the tax base and private enterprises as sources of revenue in the municipal budget that provides the financial base for the performance of its obligations for the population of the municipality (Voronin, Lapin \& Shirokov, 1998). The specifics of economic relations in the municipal sector with the objective necessity creates the dualism of municipal economy (Ivanov, 2001), the essence of which is that two types of diverse interests are faced-the local authority and the population living on its territory. Thus the main task, the functions of local authorities are often in conflict with economic space dominated by a complex system of economic relations associated with the production, distribution, redistribution, 
exchange and consumption of goods and services within the territorial education (Zotov \& Makasheva, 2004), as well as with the immediate interests of employees of local authorities. In this connection, the problem how to overcome the contradictions of municipal economy related to the difference of economic interests under the municipal economy, (Ignatov, 2002), as well as the absence of the actual benefits of municipal economy over other forms are greatly updated. (Koveshnikov, 2002). The latter is particularly actualizes economic methods of municipal economy management, as they face up a range of problems, starting with the characteristics of natural monopoly industries and finishing with the extremely low level of their own financial base in most municipalities. All this with the objective necessity especially requires in-depth studies of the specificity of domestic municipal economy and its foreign models.

\section{Methodological Framework}

\subsection{Objectives of the Study}

The objective of this study is to identify the organizational, economic and managerial rivalries in the economic relations of municipal services that are hampering the development of the municipal economy.

\subsection{Theoretical and Methodological Basis}

Theoretical and methodological basis of the study are the fundamental principles of the economic theory, the theory of municipal management, scientific works of domestic and foreign scholars on the economic bases' problems of local authorities' activity, policy documents and regulations of public authorities, Federal and regional normative legal acts published in the official press.

Methodological basis of the study is the comprehensive use of wide range of different techniques of situational, dynamic, comparative, structural and functional analysis, graphical interpretation of the actual data.

\section{Results}

\subsection{The Interpretation of the Notion "Municipal Economy"}

Municipality formations fulfill their activity under market economic space dominated by a complex system of economic relations connected with the production, distribution, redistribution, exchange and consumption of goods and services within the territorial formation. This economic system is the institutional framework of the municipal economy.

In addition, taking into account that the legislation does not provide any legal definition of "municipal economy", researchers interpret it in different ways, sometimes contradicting each other. So, some of them understand it as "a system of economic relations, which come in the local authorities in the process of production, distribution, exchange and consumption of material goods and services on the territory of municipal formation (Ivanov, 2001).

Others include in the concept of municipal economy such components as the activities of the local authorities to ensure the collective needs of the population, and utilities on the basis of municipal property, all economic entities on the territory of municipal formation, business in a given territory entities, irrespective of forms of ownership, which ensure the collective needs of the population of the municipality, the process of interaction between the public and local agencies with material environment, aimed at ensuring the livelihoods of people living in the area, as well as economic relations between all parties regarding the production and reproduction of goods (Aksanov, 2004).

In its turn, the number of specialists connects this concept with the collective needs of the population of the municipality, considering the municipal economy as "the activities of the local authorities to ensure the collective needs of the local community" (Kournikova, 2005). However, the author forgets about the competence of local authorities in the framework of problems of local value.

Thus, municipal economy can be identified as a system of interaction and the objective existence of all its participants' interests' conflict which is shown schematically in Fig. 1. 


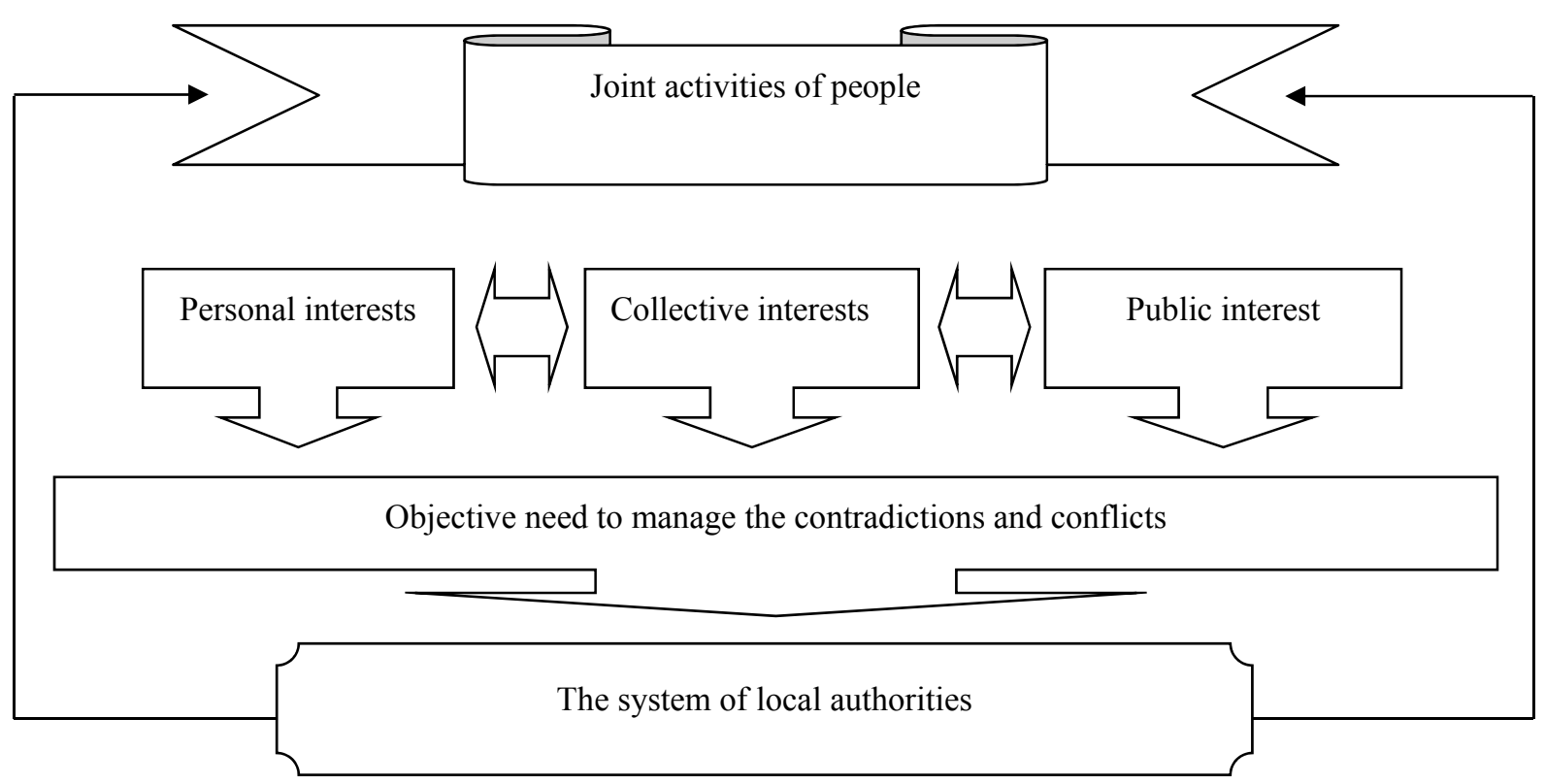

Figure 1. The Interaction of different levels of interest in the system of municipal management

So criticizing this position, experts note that often in research the concept of "municipal economy" is determined through a set of relationships between business entities on the territory of municipal formation in isolation from the activities of the municipal management system. Moreover, "municipal economy" is the joint activities of agencies related to the implementation of local authorities and economic entities on the territory of municipal formation regardless of their organizational-legal form of ownership associated with the problems' solving of local value. Under the concept of "territorial economy" the author means the activities of enterprises and institutions related to municipal entity only by issues of tax payments or the use of municipal property. The "municipal economy" as a concept can exist and be used only during the presence of both components (Shurilov, 2011).

\subsection{Dualism of Local Authorities' Position in the System of Municipal Economic Relations}

The most important task of local authorities is the provision of integrated solution of problems connected with services, the development of education, health and culture, housing and utilities, social services, using the mechanisms and tools of municipal economy. It is important that the municipal economy functions under the united Russian economic space and is based on the main reproductive resources and factors of production, which are represented both by private and public entities. While the public sector is mostly focused on costly, inefficient social needs of the population of the municipalities, which traditionally include health, education, social assistance and social work, security and the maintenance of public order, the private sector, as a rule, is oriented on the market, developing industry, trade, mediation, small and medium enterprises and peasant (farmer's) economy, etc.

However, within the jurisdiction of local value the important place in activity of the municipal enterprises is taken by the activity connected with providing the population of the municipality with housing and communal services and, above all, gas, electricity, water, sewer service, removal and recycling services, urban and suburban passenger transport, catering and many others.

Dualism of local authorities' position in the system of municipal economic relations, on the one hand, means that they perform a regulatory function in the system of economic relations, on the other - through municipal enterprises they become the rightful entities of economic relations, with their own economic potential in the form of the local budget, municipal property, etc. Positioning of local authorities in the system of economic relations as an independent economic entity allows them to build their own economic system and manage financial, land, material and other resources owned by them on the principles of commerce and economic calculation that assumes a certain income. However, the use of this income in other purposes of the municipality which do not include meeting the interests and needs of the population is prohibited by law.

On this occasion L. A. Velikhov writes that municipal structures and municipal enterprises in their activities' implementation pursue the "goal not of individual enrichment and personal gain by ordinary assignment of 
generated in the economy the surplus value, but socially useful purpose" (Velikhov, 1995).

In this regard quite clear is the position, according to which the system of local authorities is associated with the principles of shareholder structures' constructing in where the shareholders are all residents of the municipality, and the dividends received by them are social services, goods and public goods. This allegory reflects, primarily, the public nature of municipal economy, public nature of local authorities' activity, as well as the collective nature of the appropriation of wealth created in the system of municipal services (Voronin, Lapin, Shirokov, 1998).

\subsection{Classification of Business Entities under the Municipal Economy}

Based on the analysis of local authorities system's economic foundations, it seems necessary to classify economic entities within the municipal economy, which by law are divided into:

- municipal institutions and enterprises in structure of property of which the municipality owns this or that part of property or becomes the ultimate its owner;

- companies and institutions of public, private, joint stock, limited and other forms of ownership (Fig. 2).

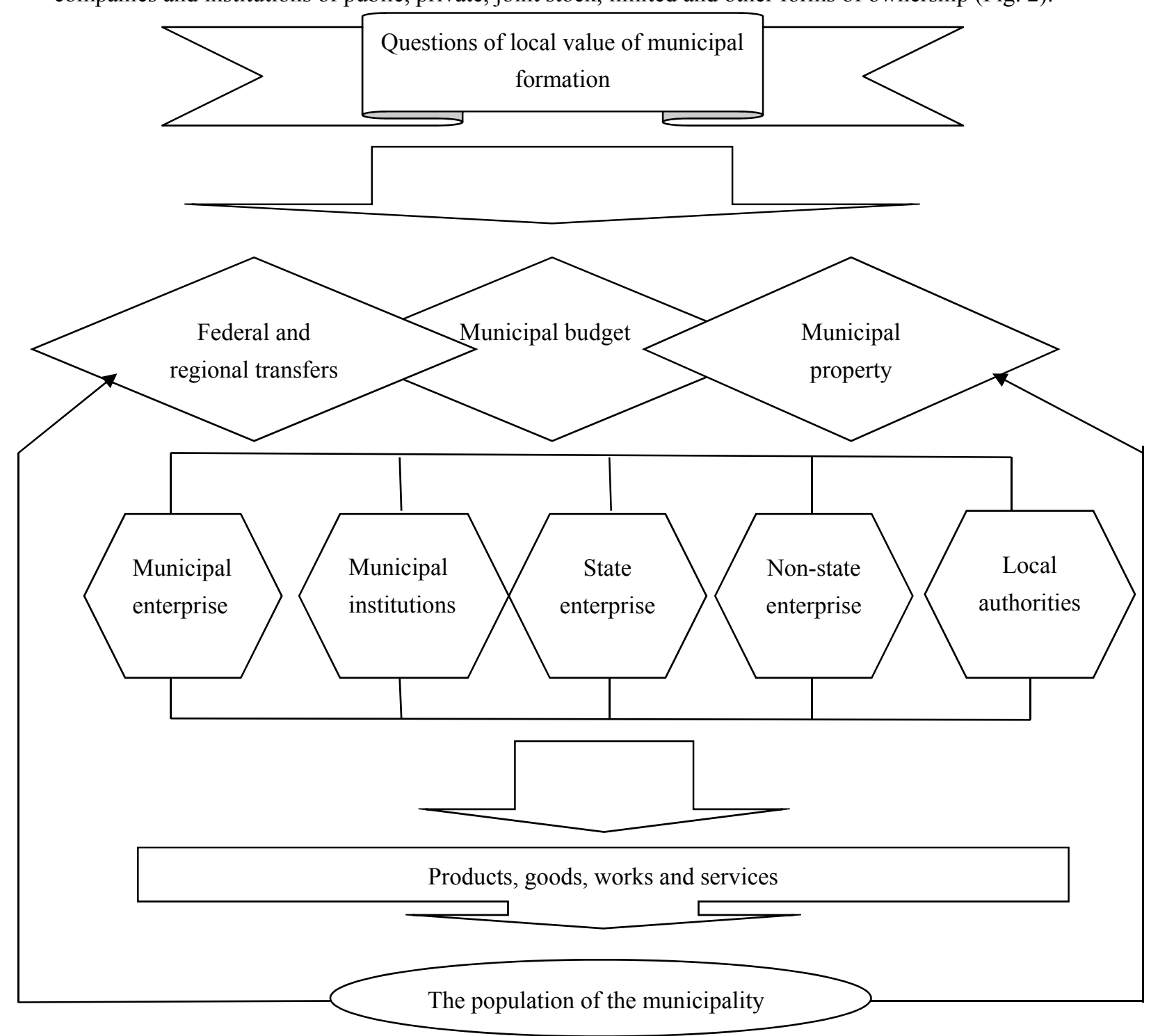

Figure 2. Organizational and managerial structure of the functioning of municipal services' system

Both mentioned types of business entities of municipal economies are subjected to direct regulatory influence of local authorities. In other words, "as an entity who has by law the right to regulate economic activity on its territory, each local authority body with the necessity implements powers in respect of any business entity 
operating within the municipality. The combination of these powers allows municipalities in varying degrees to subordinate the activities of all enterprises and institutions located on the territory of the municipality, to meet the needs of citizens" (Ignatov \& Rudoy, 2005).

However, the problem how to choose companies of any form of ownership for implementing the local authorities' functions still remains quite controversial and now.

\subsection{The Inconsistency of the Advantages of Municipal Ownership in Comparison with Other Forms}

So, experts claim that for the population of the municipality is more profitable to deal with municipal enterprises owned by the municipality. In favor of this argument experts use the following arguments:

- if enterprises of non-public form of property encumbered only by deduction of tax at the municipal level, the municipal enterprises give into the ownership of the municipality, all of the income resulting from economic activity that most contributes to the strengthening of the financial base of local authorities;

- if enterprises of non-public form of ownership are not directly subordinated to the local authorities, municipal enterprises, being in fact their property are subjected to the direct control and management, which is reflected in the definition of statutory objectives, the procedure and conditions for economic activity, regulation of prices and tariffs for services, the appointment and dismissal of the head of the company (Ignatov \& Rudoy, 2005).

However, this view seems to us to be somewhat one-sided, because it does not consider the industrial specifics of private, public and municipal enterprises and institutions' functioning. So, municipal enterprises clearly are unacceptable by their organizational and economic structure in a number of housing and communal complex's branches related to the operation of natural monopolies, which include gas and electricity. Here, as in the production and transmission (networks) the dominant role belongs to state-owned companies. Fundamentally wrong to transfer the ownership of transportation and transfer of these resources to municipal enterprises, as they haven't the necessary financial and material resources to ensure the required level of capacity of these networks.

As practice shows, the effectiveness of the municipal medical institutions is extremely low both as from medical and so economic point of view, because the low level of medical equipment and personnel provision does not allow them to provide the proper level of medical services and actively to develop paid medical services in excess of the program of state guarantees providing free medical services. In fact, the municipal medical institutions seek only to earn some money by illegal extension of paid medical services.

Thus, the provision of population with hotel facilities in health care institutions, as well as additional diagnostic tests and therapeutic services, clinical laboratory tests, plastic surgery and dentistry and other medical services which are not included into the state guarantees program of free medical care rendering for region population, can be most efficiently organized by private medical organizations having a license for these types of medical care.

The same tendencies can be observed in education, sports clubs' organization, schools and leisure activities' organizing, in other words, in those areas where the demand for qualified services is quite high and exceeds the capacity to deliver them by municipal enterprises and institutions. Advantages of private organizations in these areas are based on market mechanisms of these economic structures owners' personal material interest and may be subjected to local governments' regulation by both as direct so indirect methods, including the main access to municipal orders and their implementation. Thus, the costs of private organizations for the implementation of those or other economic projects of local authorities may be substantially less than the cost of municipal enterprises for a number of reasons both subjective and objective nature.

\subsection{Contradictions of Economic Relations' Classification of Municipal Services on Property and Moral Ones}

In the economic literature on economic problems of local authorities systems functioning, a number of specialists, this relationships' set traditionally divide into pecuniary and non-pecuniary economic relations. Under property relations they understand the relations which are connected with the use, disposal, operational management, commercial management, lease, pledge and mortgage of municipal property. Economic entities of these relations are the administration of the municipality and the municipal entity entitled to the rightful use of municipal property in accordance with the agreement (Gutman, 2003). In this case the municipal entity have the right to operate and manage the property of the municipality in order to solve problems of local importance and it is not allowed to make transactions in respect of the property and takes the administrative and economic responsibility before the local administration for its safety (Koveshnikov, 2002).

In its turn, non-property relations deals with municipal properties' use by specific municipal enterprises and allow, in their opinion, the local administration to determine the range and volume of production of the most 
popular products and services for the local population, the level of costs and prices for their production, accounting and reporting, as well as the participation of the representatives of the local administration in the management bodies. However, as practice shows, this is far from reality.

Most deeply the contradiction between property and non-property relationship develops between a large state and non-state enterprises located on the territory of a municipality. Essentially the company becomes financially and revenue generating business entity not only for the municipality but for the region as a whole. It is quite obvious that, in spite of the size and nature of the activities of such enterprise it is not able to function completely independently from the territory in which it is located, as it needs land, water, electricity, gas, access of roads and railway lines, objects of engineering infrastructure, workers and engineering personnel, system maintenance. Therefore, the economic evaluation of counter flows of these resources is the subject of a separate agreement between the administration of the municipality and the management of the enterprise, which determines or estimates in physical and value terms the contribution value of each party. If for this enterprise it will be reflected in the value of specific resources used in the production process, for the municipality this contribution will be reflected in concrete material goods and financial resources allocated for socio-economic development of the territory of municipal formation (Pikulkin, 2008).

However, we must not forget that the majority of municipalities do not possess such opportunities unfortunately. Thus, in accordance with the legislation, local authorities are intended to ensure a certain minimum of social and economic well-being, necessary for the normal existence of the inhabitants of the municipality. To ensure this minimum, which for each territory has its objective limits, respectively, municipal property and financial funds are necessary and sufficient, which should have the territory of the municipality. Of course, that would be quite logical to see the economic potential of the municipality which is not available in big cities and the budget of the enterprise, but directly dependent on the effective functioning of its administration, as is assumed in most developed countries. However, a number of municipalities objectively do not possess the necessary amounts of material and resource potentials of development, while others have them in abundance. In other words, ceteris paribus, natural resource base of economic activity of the majority of municipalities in Russia is significantly different. Therefore, the law imposes on public authorities a direct obligation in providing municipalities with the necessary minimum conditions of life for their populations in case of the absence of objective potential opportunities for achieving this minimum by the administration of municipalities.

Thus, if the local authorities have neither the tax base nor sufficient municipal property, which would bring in the necessary income, they are forced to be engaged in property relations with higher authorities, including the transfer of the regional or Federal property to the municipality, the governing enrollment of revenue sources and transfer payments to local budgets, as well as the government programs' direct funding for socio-economic development of municipalities (Ignatov \& Rudoy, 2005).

Unfortunately, the division of property and non-property relations of the municipal economy generates dependency relations of the administration of local authorities in solving local issues.

\subsection{The Failure of Municipal Economy for Their Own Economic Independence Ensuring}

The situation in the world economy, the consequences of a deep global financial crisis, low economic growth and the development of market relations in the domestic economy with the objective evidence force to acknowledge that to ensure the economic independence of municipalities due to objective reasons, without the active participation of Federal and regional levels of government is almost impossible. They have the primary responsibility for legislative guarantees for the formation of the economic foundations of local authorities, for the reform of local taxation, for the transfer to the municipal level of property that can bring the municipalities a steady income (Timofeev, 2005).

It is difficult to imagine the assessment of local authorities' functioning efficiency without characterizing of the main application areas of local authorities' administrative actions. From the point of view of the economic content of this evaluation process, it is necessary to focus on two important functions of administrations of municipalities, which are municipal property and municipal Finance. The efficiency of these two resource categories of municipalities should be the criteria for assessing the effectiveness of the administration of local authorities. So, experts determine the municipal ownership as a system of relations for municipality population assigning through the system of local authorities with the means of production and items (goods and services) consumption, joint ownership, use and disposal of natural conditions, industrial and social infrastructure in order to meet the needs of the population of the municipality and to improve its welfare (Filippov \& Avdeyeva, 2008).

However, this definition is one-sided by nature and does not take into account the developing market relations, as well as modern trends in the ratio of municipal, regional and Federal authorities on this important economic 
resource. Moreover, the author identifies only the system of assigning by the population of wealth, losing out the sight the counter processes of formation of municipal property and its reproduction.

The duality of the substantial characteristics of municipal property is due to its very specific purpose. On the one hand, municipal ownership has quite a specific target destination, expressed in the need to meet the vital needs of the residents of the municipalities, which include housing and utilities, health, education, social, household and cultural services and is presented by the utilities, schools, hospitals and clinics, libraries and kindergartens. On the other hand, municipal property as an object of economic activity is involved in the formation of the local budget at the expense of the implementation or lease of municipal property.

\section{Discussion}

To the research of municipal economy's dual nature the works by Velikhov L. A. (1995), Voronin A. G., Lapin V. A., Shirokov A. N. (1998), Ivanov V. N. (2001), Zotov V.B., Makasheva Z. M. (2004), Leksin V. N. (2001) and others are devoted.

To the analysis of the interests' conflicts in the system of municipal services' economic relations works by Aksanov V. L. \& Melnikov, S. B. (2004), Gutman, G. V. (2003), Koveshnikov E. M. (2002), Kournikova I. V. (2005), Piculkin A. V. (2008), Shurilov A. V. (2011) and others are dedicated.

The problems of business entities' classification of different functionality and ownership within the municipal economy are investigated in the works of Ignatov V. G. \& Rudoy V. V. (2005), Timofeev N. S. (2005), Filippov, Y. V. \& Avdeeva T. T. (2008), and others.

\section{Conclusion}

Thus, the duality and contradictions of interests in functioning of the municipality is in the fact that the object of municipal management are, on the one hand, the management subsystems of the administration (human, financial, informational), and on the other hand - its functional subsystems (fully or partially depending on the form of ownership) - health, social protection, education, law enforcement, life support (housing and utilities), passenger transport, small business, credit and insurance facilities and enterprises and other organizations which in the midst of these economic contradictions significantly reduces the efficiency of the administration of the municipality and municipal economy. Big problems, greatly exacerbating these tensions are related to the lack of advantages of municipal ownership over other forms.

\section{Recommendations}

The obtained results allow systematize and classify the principal economic, organizational and managerial problems and contradictions of the activity of local authorities. Besides of it, the results obtained can be useful for the municipal authorities in the process of improving its policy within the legislatively assigned responsibilities and justifying management decisions.

\section{References}

Asanov, V. L., Ivanov, V. N., \& Melnikov, S. B. (2004). Municipal management. Moscow: Municipal world.

Filippov, Y. V., \& Avdeeva, T. T. (2008). Basis for the development of the local economy. Moscow: Delo.

Gutman, G. V. (2003). The development strategy of the municipality. Moscow: Juridical book.

Ignatov, V. G., \& Rudoy, V. V. (2005). Local authorities. Rostov n/D: Phoenix.

Ivanov, V. N. (2001). Innovative social technologies of state and municipal management. Moscow: Economics.

Kournikova, I. V. (2005). Local needs, their classification and mechanism of providing (Unpublishedmaster'sthesis). Ivanovo.

Koveshnikov, E. M. (2002). The state and local authorities in Russia: theoretical and legal bases of interaction of Moscow: Norma.

Leksin, V. N., \& Shvetsov, A. N. (2001). Municipal Russia: Socio-economic situation, law, statistics. Moscow: editorial URSS.

Pikulkin, A. B. (2008). The economy of the municipal sector. Moscow: UNITY-DANA.

Shurilov, A. (2011). The efficiency increase of local authorities' activity (Unpublished master's thesis). Ivanovo.

Timofeev, N. S. (2005). Local authorities in the system of state and social relations. History and present. The Experience of Russia. Moscow: MSU Publishing house.

Velikhov, L. A. (1995). The basis of the urban economy. Obninsk Institute of municipal management. 
Voronin, A. G. Lapin, V. A., \& Shirokov, A. N. (1998). Fundamentals of management of municipal facilities. Moscow: Delo.

Zotov, V. B., \& Makasheva, Z. M. (2004). Municipal management. Moscow: UNITY-DANA.

\section{Copyrights}

Copyright for this article is retained by the author(s), with first publication rights granted to the journal.

This is an open-access article distributed under the terms and conditions of the Creative Commons Attribution license (http://creativecommons.org/licenses/by/3.0/). 